\title{
Synthesis, Characterization and Benzene Oxidation Promoted by a New Mononuclear Copper(II) Complex, [Cu(BTMEA) $\left.)_{2} \mathrm{Cl}\right] \mathrm{Cl}$
}

\author{
Maria C. Esmelindro, ${ }^{a, b}$ Enrique G. Oestreicher, ${ }^{a}$ Marcela Caovilla, ${ }^{b}$ \\ Josane A. Lessa, ${ }^{c}$ Christiane Fernandes, ${ }^{c}$ Cláudio Dariva, ${ }^{d}$ Sílvia M. Egues, \\ Adailton J. Bortoluzzi ${ }^{e}$ and Octavio A. C. Antunes* ${ }^{*}$, \\ ${ }^{a}$ Instituto de Química, Universidade Federal do Rio de Janeiro, CT Bloco A, Lab 641, \\ Cidade Universitária, 21945-970 Rio de Janeiro-RJ, Brazil \\ ${ }^{b}$ Universidade Regional Integrada do Alto Uruguai e das Missões, Campus de Erechim, \\ 99700-000 Erechim-RS, Brazil \\ ${ }^{c}$ Laboratório de Ciências Químicas, Universidade Estadual do Norte Fluminense, \\ 28013-602 Campos dos Goytacazes-RJ, Brazil \\ ${ }^{d}$ Institute of Research and Technology, Av. Murilo Dantas, 300, \\ 49031-490 Aracaju-SE, Brazil \\ ${ }^{e}$ Departamento de Química, Universidade Federal de Santa Catarina, Trindade, \\ 88040-900 Florianópolis-SC, Brazil
}

\begin{abstract}
O objetivo deste trabalho é apresentar a síntese, estrutura cristalina, atividade eletroquímica, propriedades espectroscópicas (IV-TF e UV-Vis) e atividade catalítica frente à oxidação do benzeno do novo complexo mononuclear de cobre(II) [Cu(BTMEA) $2 \mathrm{Cl}] \mathrm{Cl}$, (1) (BTMEA: bis(2tienilmetil)-1,2-etilenodiamina). A reação entre BTMEA e $\left[\mathrm{Cu}\left(\mathrm{OH}_{2}\right)_{2}\right] \mathrm{Cl}_{2}$, em metanol, resultou em 1, o qual cristaliza como um cristal irregular azul, no grupo espacial Pnna, com $a=20,101$ (3), $b=12,094(6), c=12,741(2) \AA, V=3097,4(17) \AA^{3}, Z=4$. Em 1, o íon cobre está pentacoordenado, mostrando uma geometria de pirâmide de base quadrada distorcida. Complexo $\mathbf{1}$ apresenta dois processos redox irreverssíveis a $-0,35 \mathrm{~V}$ e $0,456 \mathrm{~V}$ versus $\mathrm{NHE}$, os quais são atribuídos ao processo redox $\mathrm{Cu}^{\mathrm{II}} / \mathrm{Cu}^{\mathrm{I}}$ e a uma reação acoplada envolvendo o ligante cloreto. A atividade catalítica de 1 foi avaliada através da reação de oxidação do benzeno, usando peróxido de hidrogênio como oxidante. Os produtos da reação (fenol e $p$-benzoquinona) foram identificados por cromatografia gasosa.
\end{abstract}

The aim of this work is to present the synthesis, crystal structure, electrochemical behavior, spectroscopic properties (FT-IR and UV-Vis) and catalytic activity toward benzene oxidation of a new mononuclear copper(II) complex [Cu(BMTEA) $\left.{ }_{2} \mathrm{Cl}\right] \mathrm{Cl}$, (1) (BTMEA: bis(2-thienylmethyl)-1,2-ethylenediamine). The reaction between BTMEA and $\left[\mathrm{Cu}\left(\mathrm{OH}_{2}\right)_{2}\right] \mathrm{Cl}_{2}$, in methanol, resulted in $\mathbf{1}$, which crystallizes as an irregular blue crystal, space group Pnna, with $a=20.101(3), b=12.094(6), c=12.741(2) \AA, V=3097.4(17) \AA^{3}$, $Z=4$. In $\mathbf{1}$, the copper ion is pentacoordinated, showing a distorted square pyramidal geometry. Complex 1 shows two irreversible redox processes at $-0.35 \mathrm{~V}$ and at $0.456 \mathrm{~V}$ versus $\mathrm{NHE}$, which are associated with the $\mathrm{Cu}$ involving the chloride ligand. The catalytic activity of $\mathbf{1}$ was evaluated through benzene oxidation reaction, using hydrogen peroxide as oxidant. Reaction products (phenol and $p$ benzoquinone) were identified by gas chromatography.

Keywords: mononuclear copper(II) complex, crystal structure, benzene oxidation

*e-mail: octavio@iq.ufrj.br 


\section{Introduction}

Selective oxidation of hydrocarbons is an important topic in view of economical and ecological use of natural raw materials. The direct and catalytic transformation of arenes to various useful chemicals via $\mathrm{C}-\mathrm{H}$ activation, is of considerable interest to chemical industries and remains a challenge to chemists. ${ }^{1}$ However, the aromatic $\mathrm{C}-\mathrm{H}$ oxidation remains one of the most challenging problems in organic synthesis. The aromatic nucleus is resistant to oxidation because of its resonance stabilization, so oxygenation almost invariably requires a highly reactive oxidant under severe conditions. In the last years, several studies have been presented in the literature using transition metal catalysts for the aromatic C-H oxidation. ${ }^{2}$

Copper complexes derived from copper chloride and crown ethers were found to be efficient catalysts. ${ }^{3}$ Recently, Reedijk and co-workers reported the catalytic polymerization of 2,6-dimethylphenol to poly(1,4phenylene ether), an industrial engineering thermoplastic, promoted by a copper complex. ${ }^{4}$

Copper complexes have been studied for the hydroxylation of benzene and the oxidation of phenol to 1,4quinone. ${ }^{2}$ Okamura et al. ${ }^{5}$ have reported the liquid phase oxidation of benzene to phenol, with molecular oxygen and $\mathrm{Cu}-\mathrm{MCM}$ as the catalyst. However, phenol yields are low, a large amount of supported $\mathrm{Cu}$ is required, and ascorbic acid is used as a stoichiometric coreductant. Recently, some regarding the benzene oxidation using oxygen as oxidant and Cu-supported (ZSM-5) catalysts have been reported. The yield and selectivity of phenol had a maximum with respect to $\mathrm{Cu}$ contents in the CuH-ZSM-5, and were optimized with 0.77 wt. \% Cu loading (phenol yield of $4.9 \%$ ). ${ }^{6}$ Liu et al. ${ }^{7}$ reported the benzene oxidation using copper substituted in polyoxometalate (TBA-PW ${ }_{11} \mathrm{Cu}$ ) as the catalyst and molecular oxygen as the oxidant. The results showed $9.2 \%$ conversion and $91.8 \%$ selectivity to phenol in the benzene oxidation at $50{ }^{\circ} \mathrm{C}$ for $12 \mathrm{~h}$. Sun and co-workers carried out the oxidation of 2,3,6-trimethylphenol to trimethyl-1,4benzoquinone, in an ionic liquid (1-butyl-3-methylimidazolium chloride) medium using copper(II) chloride as the catalyst and molecular oxygen as the oxidant. ${ }^{8}$

Therefore, as a part of our interest in the development of new complexes with catalytic activity we wish to report the synthesis of a mononuclear copper complex [Cu(BTMEA) $\mathrm{Cl}] \mathrm{Cl}$ (1), $(\mathrm{BTMEA}=$ bis(2-thienylmethyl)-1,2-ethylenediamine), which presents labile ligand and an unsaturated coordination environment. ${ }^{9-11}$ Thus, the preparation, crystal structure, spectroscopic, electrochemical studies, and the catalytic activity toward benzene of the new complex $\mathbf{1}$ are presented.

\section{Experimental}

\section{Materials}

The chemical reagents ethylenediamine and 2-thiophene carboxaldehyde were purchased from Aldrich Chemicals Co.; sodium sulphide from Pro Analysis; copper(II) chloride dihydrate $\mathrm{CuCl}_{2} \cdot 2 \mathrm{H}_{2} \mathrm{O}$ and hydrogen peroxide (30\%) from Merck. Merck supplied the solvents benzene, dichloromethane and acetonitrile. All reagents and solvents were used as received.

\section{Instrumental analysis}

Elemental $(\mathrm{C}, \mathrm{H}, \mathrm{N})$ analyses were performed in a Perkin Elmer $2400 \mathrm{CHN}$ analyzer. Infrared spectra were recorded in $\mathrm{KBr}$ disks in a Nicolet Magna-IR 760. Nuclear magnetic resonance analyses were conducted in a Bruker DRX-200 spectrometer, at $200 \mathrm{MHz}$ for ${ }^{1} \mathrm{H}-\mathrm{NMR}$ and 50 $\mathrm{MHz}$ for ${ }^{13} \mathrm{C}-\mathrm{NMR}$, in $\mathrm{CDCl}_{3}$. Cyclic voltammograms $(\mathrm{CVs})$ were carried out in an Autolab PGSTAT 10 potentiostat/galvanostat in dimethylformamide containing $0.1 \mathrm{~mol} \mathrm{~L}^{-1}$ litium perchlorate $\left(\mathrm{LiClO}_{4}\right)$ as supporting electrolyte under argon atmosphere at room temperature. The CVs were obtained at $25,50,75$ and $100 \mathrm{mV} \mathrm{s}^{-1}$, under argon atmosphere at room temperature. The electrochemical cell employed was a standard threeelectrode configuration: a glassy carbon working electrode, a platinum-wire auxiliary electrode and a commercial $\mathrm{Ag} / \mathrm{AgCl}$ electrode immersed in a salt bridge containing $0.1 \mathrm{~mol} \mathrm{~L}^{-1} \mathrm{TBAClO}_{4}$. The formal potential of the ferrocenium/ferrocene couple was $0.416 \mathrm{~V} v s$. the reference electrode $\mathrm{Ag} / \mathrm{AgCl}$. The electrical conductivity of $1 \times 10^{-3} \mathrm{~mol} \mathrm{~L}^{-1}$ solution of $\mathbf{1}$ was measured with a Lutron Cd-4301 conductometer. The electronic absorption spectra (300-1100 nm range) were recorded in $\mathrm{CH}_{3} \mathrm{CN}$, utilizing an Agilent 8453 E UV-Vis spectrophotometer.

Synthesis of bis(2-thienylmethyl)-1,2-ethylenediamine (BTMEA)

The pro-ligand BTMEA was prepared by the condensation reaction between ethylenediamine and 2-thiophene carboxaldehyde, followed reduction by sodium borohydride $\left(\mathrm{NaBH}_{4}\right)$, which has been previously reported. ${ }^{12}$

\section{Synthesis of $\left[\mathrm{Cu}(\mathrm{II})(\mathrm{BTMEA})_{2} \mathrm{Cl}\right] \mathrm{Cl},(\mathbf{1})$}

A methanolic solution $(10 \mathrm{~mL})$ of $\mathrm{CuCl}_{2} \cdot 2 \mathrm{H}_{2} \mathrm{O}(1$ mmol, $170 \mathrm{mg}$ ) was slowly added to a methanolic solution $(10 \mathrm{~mL})$ of the ligand BTMEA ( $2 \mathrm{mmol}, 504 \mathrm{mg})$, 
resulting in a deep blue solution. The solution was stirred for $3 \mathrm{~h}$ and the formation of a blue solid was observed during this period. The solution was then filtered and the solid was recrystallized in methanol/acetonitrile (1:1). The solution was allowed to stand at $10{ }^{\circ} \mathrm{C}$ for $24 \mathrm{~h}$. Dark-blue single crystals were formed and were filtered off. Yield: $74 \%, 250 \mathrm{mg}$.

\section{$X$-ray crystallography}

Crystal data. $\mathrm{C}_{24} \mathrm{H}_{32} \mathrm{Cl}_{2} \mathrm{CuN}_{4} \mathrm{~S}_{4}, \mathrm{MW}=639.22$, orthorhombic, space group Pnna, $a=20.101(3), b=$ 12.094(6), $c=12.741(2) \AA, V=3097.4(17) \AA^{3}, T=293(2)$ $\mathrm{K}, Z=4, \mu(\mathrm{Mo}-\mathrm{K} \alpha)=1.167 \mathrm{~mm}^{-1}, D_{c}=1.371 \mathrm{~g} . \mathrm{cm}^{-3}$, 2736 unique $\left(\mathrm{R}_{\text {int }}=0.000\right), 172$ parameters, $\mathrm{GoF}=1.035$, final indices: $\mathrm{R}[\mathrm{I}>2 \sigma(\mathrm{I})]=0.0399$ and $\mathrm{wR}\left(\mathrm{F}^{2}\right)=0.1107$ (all data). An irregular blue crystal was selected from the crystalline sample of complex 1 under polarized light and fixed at the end of a glass fiber for X-ray analysis. The intensity data was collected with an Enraf-Nonius CAD4 diffractometer, at room temperature, with graphitemonochromated Mo K $\alpha$ radiation. Cell parameters were determined from 25 reflections in the q range 8.40-15.23 using a standard procedure. ${ }^{13}$ All data were corrected for Lorentz and polarization effects. ${ }^{14}$ An empirical absorption correction based on the azimuthal scans of 7 appropriate reflections was also applied to the collected intensities with PLATON program $\left(\mathrm{T}_{\min }=0.587 ; \mathrm{T}_{\max }=0.688\right) .{ }^{15} \mathrm{The}$ structure was solved by direct methods and refined by fullmatrix least-squares methods using SIR $97^{16}$ and SHELXL97 ${ }^{17}$ programs. All non-hydrogen atoms were refined anisotropically. $\mathrm{H}$ atoms attached to $\mathrm{C}$ atoms were placed at their idealized positions, with $\mathrm{C}-\mathrm{H}$ distances and $U_{\text {eq }}$ values taken from the default settings of the refinement program. The $\mathrm{H}$ atoms of the amine groups were found from Fourier difference map and treated with riding model. The ring $\mathrm{C} 21 / \mathrm{C} 22 / \mathrm{C} 23 / \mathrm{C} 24 / \mathrm{S} 2$ shows a rotational disorder, where the $\mathrm{C} 22$ and S2 occupy two alternative positions with refined occupancy factors of $0.520(6)$ and $0.480(6)$.

\section{Catalytic Activity}

The catalytic activity was performed through the benzene oxidation reaction using hydrogen peroxide $\left(\mathrm{H}_{2} \mathrm{O}_{2} 30 \%\right.$ in water) as oxidant. It was evaluated the influence of temperature ( 25 to $40{ }^{\circ} \mathrm{C}$ ), solvent (dichloromethane or acetonitrile), catalyst and oxidant concentration $\left(7 \times 10^{-4}\right.$ to $\left.1.5 \times 10^{-3} \mathrm{~mol} \mathrm{~L}^{-1}\right)$ and $\left(0.385\right.$ to $\left.0.77 \mathrm{~mol} \mathrm{~L}^{-1}\right)$ on the conversion and selectivity. The experimental conditions were determined by a semi-factorial $2^{4-1}$ experimental design. ${ }^{18}$ The experimental range investigated was determined based on
Table 1. Crystal data and structure refinement for complex 1

\begin{tabular}{ll}
\hline Formula & $\mathrm{C}_{24} \mathrm{H}_{32} \mathrm{Cl}_{2} \mathrm{CuN}_{4} \mathrm{~S}_{4}$ \\
Formula weight & 639.22 \\
Crystal system & Orthorhombic \\
Space group & $\mathrm{P} \mathrm{n} \mathrm{n} \mathrm{a}$ \\
Unit cell dimensions & $\mathrm{a}=20.101(3) \AA$ \\
& $\mathrm{b}=12.094(6) \AA$ \\
& $\mathrm{c}=12.741(2) \AA$ \\
Volume & $3097.4(17) \AA 3$ \\
$\mathrm{Z}$ & 4 \\
$\rho_{\text {calc }}$ & $1.371 \mathrm{~g} \mathrm{~cm}^{-3}$ \\
$\mu$ & $1.167 \mathrm{~mm}-1$ \\
$\mathrm{~F}(000)$ & 1324 \\
Crystal size & $0.50 \times 0.46 \times 0.33 \mathrm{~mm} 3$ \\
$\theta$ range & 1.89 to $25.00^{\circ}$ \\
Index ranges & $-23 \leq \mathrm{h} \leq 0,-14 \leq \mathrm{k} \leq 0,-15 \leq 1 \leq 0$ \\
Reflections collected & 2736 \\
Independent reflections & $2736[\mathrm{R}(\mathrm{int})=0.0000]$ \\
Data / restraints / parameters & $2736 / 0 / 172$ \\
Goodness-of-fit on $\mathrm{F}^{2}$ & 1.035 \\
Final R indices [I $2 \sigma(\mathrm{I})]$ & $\mathrm{R} 1=0.0399, \mathrm{wR} 2=0.1025$ \\
$\mathrm{R}$ indices (all data) & $\mathrm{R} 1=0.0941, \mathrm{wR} 2=0.1107$ \\
Largest diff. peak and hole & 0.462 and $-0.263 \mathrm{e} . \AA$ - -3 \\
\hline
\end{tabular}

the previous works presented in the literature. ${ }^{19}$ The influence of variables was assessed using the Statistica ${ }^{\circledR}$ software. In all runs, control experiments (blank runs) were always carried out likewise, i.e., in the absence of the complex. All reactions were carried out at least in duplicate in $50 \mathrm{~mL}$ glass reactors. Initially, an amount of the catalyst (defined by the experimental design) and $17 \mathrm{~mL}$ of the solvent were added to the reactor. A purge with argon was performed in order to remove any residual air in the reactor. Subsequently, the oxidant and $0.016 \mathrm{~mol}(1.4 \mathrm{~mL})$ of benzene were loaded and the system was allowed to react during $8 \mathrm{~h}$ under stirring. The reaction was interrupted by the addition of $3 \mathrm{~g}$ of anhydrous sodium sulphite. The solution was then filtered and stored under refrigeration to be characterized by chromatographic analysis. The reaction conversion and selectivity were determined using gas chromatography [Varian Star 3400CX with a flame ionization detector, using a DB-Wax (30 m, $0.25 \mathrm{~mm}, 25 \mu \mathrm{m})$ column]. Column temperature was programmed from $40^{\circ} \mathrm{C}$ to $48{ }^{\circ} \mathrm{C}\left(2{ }^{\circ} \mathrm{C}\right.$ $\left.\min ^{-1}\right), 48{ }^{\circ} \mathrm{C}$ to $100{ }^{\circ} \mathrm{C} \min ^{-1}\left(10{ }^{\circ} \mathrm{C} \mathrm{min}^{-1}\right)$ and $100{ }^{\circ} \mathrm{C}$ to $175^{\circ} \mathrm{C}\left(12{ }^{\circ} \mathrm{C} \mathrm{min}^{-1}\right)$. All analyses were replicated at least two times. In order to quantify the products formed during the reaction, authentic standards and an internal standard (biphenyl) were employed.

\section{Results and Discussion}

\section{Synthesis and characterization}

The pro-ligand BTMEA was characterized by IR, ${ }^{1} \mathrm{H}$ and ${ }^{13} \mathrm{C}$ RMN. The results of the infrared (IR - KBr) 
analysis indicated the following bands: $3308 \mathrm{~cm}^{-1}(\mathrm{~N}-\mathrm{H})$; 3102 and $3081 \mathrm{~cm}^{-1}$ (aromatic C-H); $2922 \mathrm{~cm}^{-1}$ (aliphatic $\mathrm{C}-\mathrm{H}) ; 1441 \mathrm{~cm}^{-1}$ (aromatic $\mathrm{C}=\mathrm{C}$ ); 1276 and $1218 \mathrm{~cm}^{-1}$ (aliphatic $\mathrm{C}-\mathrm{N}$ ) and $703 \mathrm{~cm}^{-1}$ (aromatic ring). The ${ }^{1} \mathrm{H} \mathrm{NMR}$ $\delta$ (ppm): $7.22(2 \mathrm{H} ; \alpha \mathrm{H}), 6.95(2 \mathrm{H} ; \beta 1 \mathrm{H}), 3.99(2 \mathrm{H} ; \beta$ $2 \mathrm{H}), 2.80$ (4H; $\mathrm{CH} 2), 2.03$ (4H; CH2). ${ }^{13} \mathrm{C}$ NMR: $\delta(\mathrm{ppm})$ $144.2(2 \mathrm{C} ; \delta \mathrm{C}), 126.7(2 \mathrm{C} ; \alpha \mathrm{C}), 125.0(2 \mathrm{C} ; \beta 1 \mathrm{C}), 124.5$ (2C; $\beta 2 \mathrm{C}), 48.4$ (2C; $\mathrm{CH} 2), 47.6(2 \mathrm{C} ; \mathrm{CH} 2)$. The structure of the pro-ligand is presented in Figure 1.

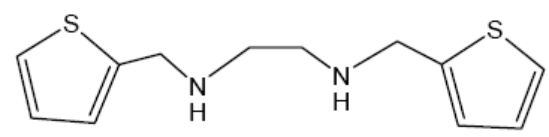

Figure 1. Structure for the pro-ligand bis(2-thienylmethyl)-1,2-ethylenediamine (BTMEA).

The complex [Cu$\left.{ }^{\mathrm{II}}(\mathrm{BTMEA})_{2} \mathrm{Cl}\right] \mathrm{Cl}$ (1) was prepared by the reaction between $\left[\mathrm{Cu}\left(\mathrm{OH}_{2}\right)_{2} \cdot \mathrm{Cl}_{2}\right]$ and the pro-ligand BTMEA, in methanol, using the ratio 1:2. The crystalline material obtained was characterized by IR and UV-Vis spectroscopies, electrochemistry, elemental analysis, conductivity and X-ray diffraction. The conductivity measurement in methanolic solution $\left(1 \times 10^{-3} \mathrm{~mol} \mathrm{~L}^{-1}\right)$ at $25^{\circ} \mathrm{C}\left(\Lambda_{\mathrm{M}}=80.5 \Omega^{-1} \mathrm{~cm}^{2} \mathrm{~mol}^{-1}\right)$ is consistent with a $1: 1$ electrolyte, according to Geary. ${ }^{20}$

The infrared spectrum for the title compound shows the characteristic bands of the respective ligand; 3427 (NH), 3104 and 3001 (aromatic C-H), 2947, 2883, 2860 (aliphatic C-H), $1437(\mathrm{C}=\mathrm{C}), 1229$ (aliphatic C-N) and $709 \mathrm{~cm}^{-1}$ (aromatic ring).

The electronic spectrum of $\mathbf{1}$, in methanol, displays an intense band at $240 \mathrm{~nm}\left(\varepsilon=3.12 \times 10^{4} \mathrm{dm}^{3} \mathrm{~mol}^{-1} \mathrm{~cm}^{-1}\right)$, which is attributed to the intraligand charge transfer transition $\left(\pi \rightarrow \pi^{*}\right)$. The broad band in the region of 300 $\mathrm{nm}\left(\varepsilon=0.26 \times 10^{4} \mathrm{dm}^{3} \mathrm{~mol}^{-1} \mathrm{~cm}^{-1}\right)$ is also attributed to charge transfer transitions. We suggest that it appears due to $\mathrm{Cl} \rightarrow \mathrm{Cu}^{2+}$ LMCT.

The elemental CHN results obtained were C:45.18; $\mathrm{H}: 5.11$ and $\mathrm{N}: 8.69 \%$. The calculated values for $639.22 \mathrm{~g}$ mol $^{-1}$ were $\mathrm{C}: 45.05 ; \mathrm{H}: 5.00$ and $\mathrm{N}: 8.76 \%$.

\section{Crystal structure of $\left[\mathrm{Cu}(\mathrm{BTMEA})_{2} \mathrm{Cl}\right] \mathrm{Cl},(\mathbf{1})$}

X-ray crystallography revealed $\mathbf{1}$ to be a mononuclear $\mathrm{Cu}^{\mathrm{II}}$ complex with $\mathrm{C} 2$ local symmetry, where the $\mathrm{Cu} 1$ and $\mathrm{Cl1}$ atoms are in special positions lying on the crystallographic two fold axis. The copper ion shows a characteristic and distorted square pyramidal geometry with $\tau$ parameter of $0.15 .{ }^{21}$ The coordination sphere of the $\mathrm{Cu}^{\mathrm{II}}$ is formed by two molecules of BTMEA ligand coordinated to the metal center through four aminic $\mathrm{N}$ atoms and the coordinated $\mathrm{Cl}^{-}$.
The equatorial plane contains four $\mathrm{Cu}-\mathrm{N}_{\text {amine }}$ [2.070(3) $\AA$ and 2.082(3) $\AA$ ] whereas the apical position is occupied by one chloride, resulting in $\mathrm{Cu}-\mathrm{Cl}=2.398(14) \AA$. The bond lengths are in the range expected for this coordination geometry with copper(II).

A perspective view of the cation is displayed in Figure 2 and the selected bond lengths and angles are presented in Table 2.

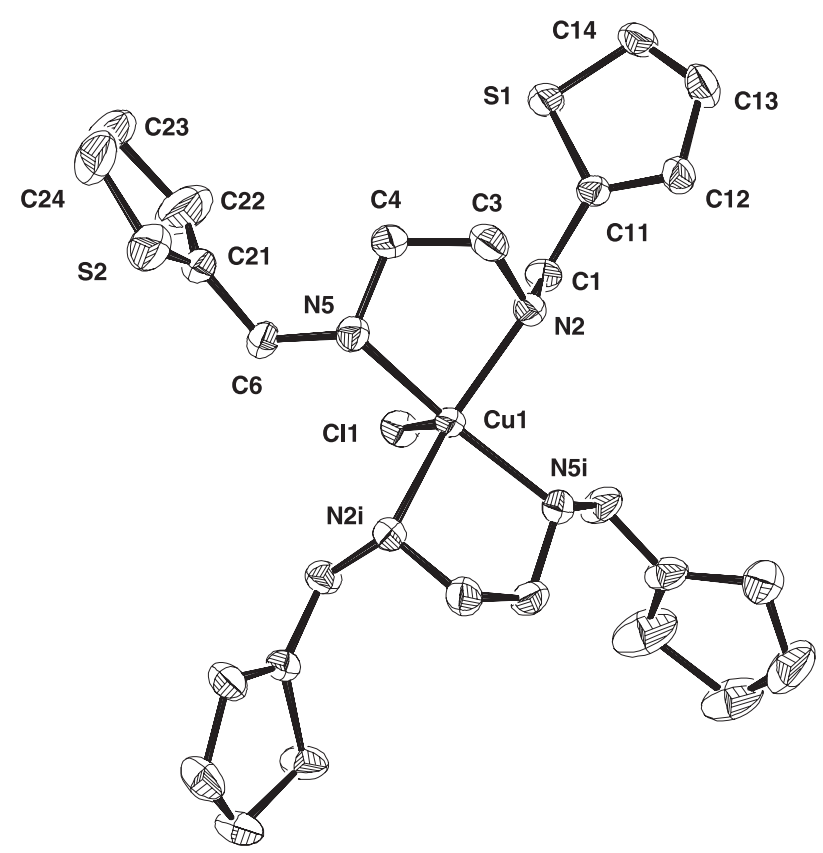

Figure 2. ZORTEP for the cation $\left[\mathrm{Cu}^{\mathrm{II}}(\mathrm{BTMEA})_{2} \mathrm{Cl}\right]^{+} \mathbf{1}$.

Table 2. Selected bond lengths $(\AA)$ and angles $\left(^{\circ}\right)$ for complex $\mathbf{1}$

\begin{tabular}{lc}
\hline Cu1-N2 & $2.070(3)$ \\
Cu1-N5 & $2.082(3)$ \\
Cu1-Cl1 & $2.398(14)$ \\
N2-Cu1-N2i & $153.33(17)$ \\
N2-Cu1-N5 & $83.53(11)$ \\
N2i-Cu1-N5 & $92.47(12)$ \\
N5-Cu1-N5i & $162.68(18)$ \\
N2-Cu1-Cl1 & $103.34(9)$ \\
N5-Cu1-Cl1 & $98.66(9)$ \\
\hline
\end{tabular}

\section{Electrochemistry}

The electrochemical behaviour of the compound 1 has been investigated by cyclic voltammetry in dimetylformamide (Figure 3). Two irreversible redox processes are observed; one at $-0.35 \mathrm{~V}$ and another at $0.456 \mathrm{~V}$ versus NHE. Both of the redox processes are very apart, indicating the presence of a coupled reaction involving the chloride, resulting in the formation of distinct compounds in solution. The process at -0.35 $\mathrm{V}$ versus NHE can be attributed to the redox process 
$\mathrm{Cu}^{\mathrm{II}} / \mathrm{Cu}^{\mathrm{I}}$ with concomitant loss of the chloride ligand, resulting in a tetracoordinated $\mathrm{Cu}^{\mathrm{I}}$ compound. At 0.456 $\mathrm{V}$ versus NHE the oxidation of the $\mathrm{Cu}^{\mathrm{I}}$ complex is observed, resulting in a pentacoordinated $\mathrm{Cu}^{\mathrm{II}}$ complex, due the coordination with the chloride ligand. Repetitive CV scans of $\mathbf{1}$ show that the redox couple is maintained with no significant decrease in either cathodic or anodic waves.

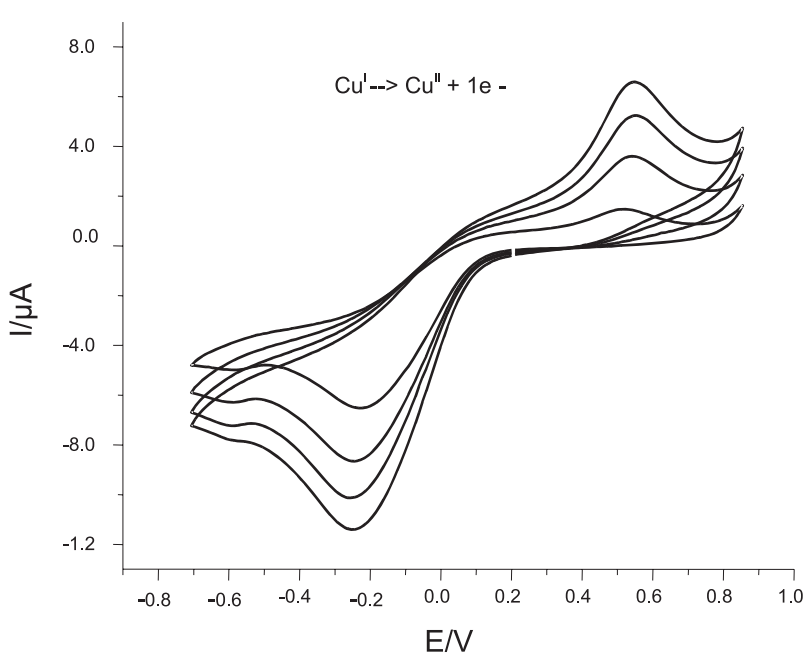

Figure 3. Cyclic voltamogram for complex $\mathbf{1}$ in dimethylformamide, at $25,50,75$ and $100 \mathrm{mV} / \mathrm{s}$.

\section{Catalytic tests}

The catalytic tests were performed through the benzene oxidation reaction. The conversion of this substrate in phenol and $p$-benzoquinone was quantified based on the injection of authentic and internal standards by gas chromatography. The experimental conditions and conversions obtaining with the complex $\left[\mathrm{Cu}^{\mathrm{II}}(\mathrm{BTMEA})_{2} \mathrm{Cl}\right] \mathrm{Cl} \mathbf{1}$ as catalyst are presented in Table 3. Conversion around 9\% (2.23\% of phenol and $6.72 \%$ of $p$-benzoquinone), at temperature of $40{ }^{\circ} \mathrm{C}$ was observed, employing higher levels of oxidant and catalyst $\left(0.77 \mathrm{~mol} \mathrm{~L}^{-1}\right.$ and $1.5 \times 10^{-3} \mathrm{~mol} \mathrm{~L}^{-1}$, respectively), and using acetonitrile as solvent. Reactions in the presence of dichloromethane as solvent presented very low conversions. From the results presented in Table 3, it is possible to observe that the conversions in $p$-benzoquinone are always higher than those in phenol, indicating that the catalyst is selective towards $p$-benzoquinone production. Mechanism proposed by Frank et al. shows that the reaction of oxygen with benzene leads to phenoxy radicals, wich can react further either to phenol or to phenoxy $+\mathrm{H}$. This radical can react with oxygen leading the formation of a ketone, namely $p$-benzoquinone.

A statistical analysis was performed in order to identify the effects of the independent variables on the conversions of benzene to phenol and p-benzoquinone. The analysis was performed using a confidence level of $95 \%$ in the Statistica ${ }^{\circledast}$ software. The results indicated that for both products, only the solvent type was significant. The other variables studied did not present a significant effect at a $95 \%$ confidence level in the experimental range investigated.

The kinetic results of the benzene oxidation are presented in Table 4 and Figure 4 (the experimental conditions chosen were those that afforded the higher conversions as shown above). It can be seen that reaction yields (phenol and $p$-benzoquinone) increase with time. However, catalyst efficiency (number of turnovers $\mathrm{h}^{-1}$ ) decreases with time, indicating that in longer reaction times, catalytic efficiency could be lost.

Although the yield of phenol is still not high, these reactions in mild conditions represent a new approach for phenol synthesis. The direct synthesis of phenol from benzene is of the greatest interest to chemical industry, and the findings of other new catalytic systems have been reported but not industrialized yet. ${ }^{23-25}$

Table 3. Results obtained for the oxidation of benzene employing $\left[\mathrm{Cu}(\mathrm{II})(\mathrm{BTMEA})_{2} \mathrm{Cl}\right] \mathrm{Cl} \mathbf{1}$, as catalyst (All results presented refers to $8 \mathrm{~h}$ of reaction)

\begin{tabular}{|c|c|c|c|c|c|c|c|}
\hline Exp. & Catalyst/(mol L-1) & Oxidant $/\left(\mathrm{mol} \mathrm{L}^{-1}\right)$ & $\mathrm{T} /{ }^{\circ} \mathrm{C}$ & Solvent & phenol $^{\mathrm{a}} / \%$ & $p$-benzoquinone ${ }^{\mathrm{b}} / \%$ & Turnover ${ }^{\mathrm{c}}$ \\
\hline 1 & $7 \times 10^{-4}$ & 0.77 & 25 & $\mathrm{CH}_{3} \mathrm{CN}$ & $1.91 \pm 0.82$ & $4.13 \pm 0.94$ & 3.85 \\
\hline 2 & $7 \times 10^{-4}$ & 0.385 & 25 & $\mathrm{CH}_{2} \mathrm{Cl}_{2}$ & - & - & \\
\hline 3 & $7 \times 10^{-4}$ & 0.77 & 40 & $\mathrm{CH}_{2} \mathrm{Cl}_{2}$ & $0.11 \pm 0.52$ & - & 0.07 \\
\hline 4 & $7 \times 10^{-4}$ & 0.385 & 40 & $\mathrm{CH}_{3} \mathrm{CN}$ & $0.67 \pm 0.34$ & $1.45 \pm 0.72$ & 1.35 \\
\hline 5 & $1.5 \times 10^{-3}$ & 0.77 & 25 & $\mathrm{CH}_{2} \mathrm{Cl}_{2}$ & $0.23 \pm 0.32$ & - & 0.14 \\
\hline 6 & $1.5 \times 10^{-3}$ & 0.385 & 25 & $\mathrm{CH}_{3} \mathrm{CN}$ & $1.06 \pm 0.79$ & $2.15 \pm 0.87$ & 2.04 \\
\hline 7 & $1.5 \times 10^{-3}$ & 0.77 & 40 & $\mathrm{CH}_{3} \mathrm{CN}$ & $2.23 \pm 0.91$ & $6.72 \pm 1.03$ & 5.18 \\
\hline 8 & $1.5 \times 10^{-3}$ & 0.385 & 40 & $\mathrm{CH}_{2} \mathrm{Cl}_{2}$ & $0.33 \pm 0.28$ & - & 0.21 \\
\hline 9 & $1 \times 10^{-3}$ & 0.5 & 32.5 & $\mathrm{CH}_{3} \mathrm{CN} / \mathrm{CH}_{2} \mathrm{Cl}_{2}$ & $0.12 \pm 0.22$ & - & 0.07 \\
\hline
\end{tabular}

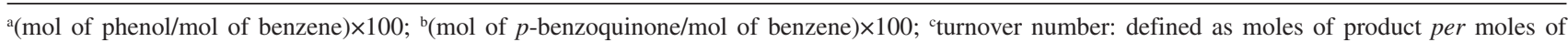
catalyst per hour. 
Table 4. Kinetic study on the oxidation of benzene employing $\left[\mathrm{Cu}(\mathrm{BTMEA})_{2} \mathrm{Cl}\right] \mathrm{Cl} \mathbf{1}$, as catalyst. Reactions conditions: $40{ }^{\circ} \mathrm{C},\left[\mathrm{H}_{2} \mathrm{O}_{2}\right]$ $=0.77 \mathrm{~mol} \mathrm{~L}^{-1}$, [catalyst] $=1.5 \times 10^{-3} \mathrm{~mol} \mathrm{~L}^{-1}$, and using $\mathrm{CH}_{3} \mathrm{CN}$ as solvent.

\begin{tabular}{|c|c|c|c|}
\hline time/h & phenol $^{\mathrm{a}} / \%$ & $p$-benzoquinone $\mathrm{e}^{\mathrm{b}} / \%$ & Turnover $^{\mathrm{c}}$ \\
\hline 1 & $0.69 \pm 0.38$ & $2.71 \pm 0.68$ & 17.68 \\
\hline 2 & $0.77 \pm 0.66$ & $3.06 \pm 0.36$ & 10.53 \\
\hline 3 & $0.99 \pm 0.21$ & $3.47 \pm 0.59$ & 7.78 \\
\hline 4 & $0.97 \pm 0.57$ & $4.61 \pm 0.93$ & 7.36 \\
\hline 5 & $1.14 \pm 0.82$ & $5.01 \pm 0.74$ & 6.22 \\
\hline 6 & $1.02 \pm 0.45$ & $5.16 \pm 0.29$ & 5.36 \\
\hline 7 & $1.21 \pm 0.70$ & $5.39 \pm 0.62$ & 4.91 \\
\hline 8 & $2.23 \pm 0.91$ & $6.72 \pm 1.03$ & 5.18 \\
\hline
\end{tabular}

a $(\mathrm{mol} \mathrm{of} \mathrm{phenol} / \mathrm{mol} \text { of benzene })^{*} 100 .{ }^{\mathrm{b}}(\mathrm{mol}$ of $p$-benzoquinone $/ \mathrm{mol}$ of benzene) $\times 100$. 'turnover number: defined as moles of product per moles of catalyst per hour.

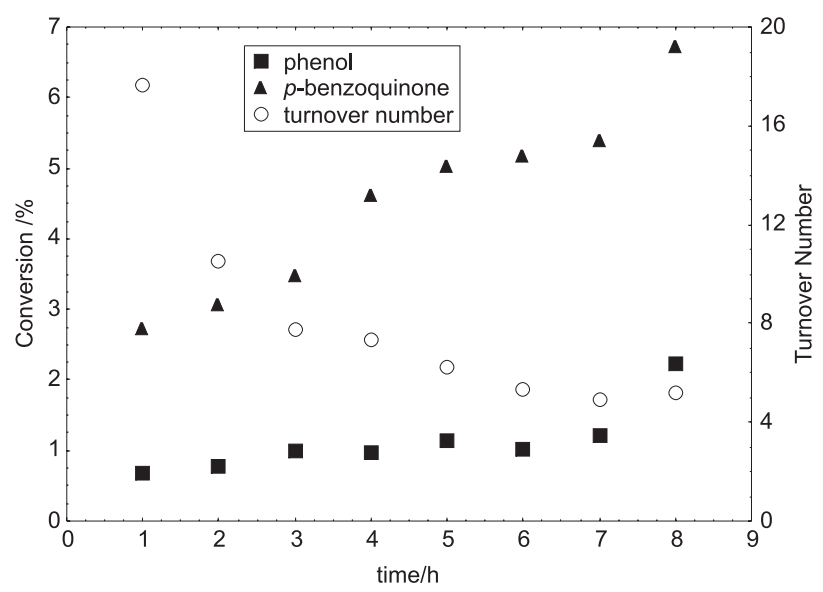

Figure 4. Kinetic results obtained in the oxidation of benzene employing $\left[\mathrm{Cu}^{\mathrm{II}}(\mathrm{BTMEA}){ }_{2} \mathrm{Cl}\right] \mathrm{Cl} \mathbf{1}$, as catalyst. Reactions conditions: $40{ }^{\circ} \mathrm{C},\left[\mathrm{H}_{2} \mathrm{O}_{2}\right]$ $=0.77 \mathrm{~mol} \mathrm{~L}^{-1}$, [catalyst] $=1.5 \times 10^{-3} \mathrm{~mol} \mathrm{~L}^{-1}$, and using $\mathrm{CH}_{3} \mathrm{CN}$ as solvent.

\section{Conclusions}

A new mononuclear copper(II) complex $\left[\mathrm{Cu}^{\mathrm{II}}(\mathrm{BTMEA})_{2} \mathrm{Cl}\right] \mathrm{Cl} \mathbf{1}$ was synthesized and characterized by spectroscopic, electrochemical and structural analyses. The experimental results indicate that complex 1 promotes the oxidation of benzene, resulting in phenol and p-benzoquinone. The results presented in this work indicate that complex $\mathbf{1}$ is not a very effective catalyst.

\section{Acknowledgments}

The authors are grateful to Petrobras (CENPES), CNPq, FINEP, FAPERJ and CAPES (PROCAD) for the financial support.

\section{Supplementary Information}

Crystallographic data for this paper have been deposited at Cambridge Structural Data Centre, deposition number CCDC 286066. These data can be obtained free of charge via http://www.ccdc.cam.ac.uk, by e-mail deposit@ccdc.cam.ac.uk or from the Cambridge Crystallographic Data Center, 12, Union Road, Cambridge CB21EZ, UK; fax: +44-1223-336-033.

\section{References}

1. Shilov, E. G.; Shul'pin, B.; Chem. Rev. 1997, 97, 2879.

2. Punniyamurthy, T.; Velusamy, S.; Iqbal, J.; Chem. Rev. 2005, 105, 2329.

3. Murahashi, S.-I.; Komiya, N.; Hayashi, Y.; Kumano, T.; Pure Appl. Chem. 2001, 73, 311.

4. Huisman, M. I.; Koval, A.; Gamez, P.; Reedijk, J.; Inorg. Chim. Acta 2005, 3591786.

5. Okamura, J.; Nishiyama, S.; Tsuruya, S.; Masai, M.; J. Mol. Catal. A: Chem. 1998, 135, 133.

6. Hamada, R.; Shibata, Y.; Nishiyama, S.; Tsuruya, S.; Phys. Chem. Chem. Phys. 2003, 5, 956.

7. Liu, Y.; Murata, K.; Inaba, M.; Catal. Commun. 2005, 6, 679.

8. Sun, H.; Harms, K.; Sundermeyer, J.; J. Am.. Chem. Soc. 2004, 126, 9550 .

9. Esmelindro, M. C.; Oestreicher, E. G.; Márquez-Alvarez, H.; Dariva, C.; Egues, S. M. S.; Fernandes, C.; Bortoluzzi, A. J.; Drago, V.; Antunes, O. A. C.; J. Inorg. Biochem. 2005, 99, 2054.

10. Carvalho, N. M. F.; Horn Jr., A.; Bortoluzzi, A. J.; Drago, V.; Antunes, O. A. C. ; Inorg. Chem. Acta 2006, 359, 90.

11. Salomão, G. C.; Olsen, M. H. N.; Drago, V.; Fernandes, C.; Cardozo Filho L.; Antunes O. A. C.; Catal. Commun., in press.

12. Sharma, V.; Khan, M. S. Y.; Eur. J. Med. Chem. 2001, 36, 651.

13. Enraf-Nonius, CAD-4 EXPRESS, Version 5.1/1.2; EnrafNonius: Delft, The Netherlands, 1994.

14. Spek, A. L.; Helena; CAD-4 Data Reduction Program, Univ. of Utrecht: The Netherlands, 1996.

15. Spek, A. L.; PLATON, Molecular Geometry and Plotting Program; Univ. of Utrecht: The Netherlands, 1997; North, A. C. T.; Phillips, D. C.; Mathews, F. S.; Acta Crystallogr. 1968, A24, 351;

16. Altomare, A.; Burla, M. C.; Camalli, M.; Cascarano, G.; Giacovazzo, C.; Guagliard, A.; Moliterni, A. G. G.; Spagna, R.; J. Appl. Cryst. 1999, 32, 115;

17. Sheldrick, G. M.; SHELXL97, Program for the Refinement of Crystal Structures; Univ. of Göttingen: Germany, 1997.

18. Montgomery, D. C.; Design and Analysis of Experiments, $4^{\text {th }}$ ed., John Wiley \& Sons: New York, 1996.

19. Vincent, J. B.; Huffman, J. C. ; Christou, G.; J. Am. Chem. Soc. 1988, 110, 6898 . 
20. Geary, W.; J. Coord. Chem. Rev. 1971, 7, 81.

21. Addison, A.W.; Rao, T. N.; van Rijn, J.; Verschoor, G. C.; J. Chem. Soc., Dalton Trans. 1984, 1349.

22. Frank, P.; Herzler, J.; Just, Th.; Wahl, C.; Proc. Combust. Inst. 1994, 25, 833.

23. Goto, S.; Seo, Y.; Mukai, Y.; Tagawa, T.; J. Mol. Catal. A: Chem. 1997, 120, 149.
24. Ishida, M. A.; Masumoto, Y.; Hamada, R.; Nishiyama, S.; Tsuruya, S.; Masai, M.; J. Chem. Soc. Perkin Trans. 1999, 2 , 847.

25. Shibata, Y.; Hamada, R.; Ueda, T.; Ichihashi, Y.; Nishiyama, S.; Tsuruya, S.; Ind. Eng. Chem. Res. 2005, 44, 8765.

26. Farrugia, L. J. J.; Appl. Crystallogr. 1997, 30, 565.

Received: May 18, 2006

Published on the web: November 7, 2006 